\title{
Anti-arteriosclerotic and Anti-hyperlipidemic Effects of Sea Mustard (Undaria pinnatifida) in Sprague-Dawley rats
}

\author{
Seung-Joo Lee ${ }^{1}$, Wang-Hyun Ha ${ }^{1}$, Hye-Jin Choi ${ }^{1}$, \\ Soon-Yeong Cho ${ }^{1 *}$ and Jong-Won $\mathrm{Choi}^{2}$ \\ ${ }^{1}$ Department of Food Processing and Distribution, Gangneung-Wonju National University, \\ Kangnung 210-702, Korea \\ ${ }^{2}$ College of Pharmacy, Kyngsung University, Busan 608-736, Korea
}

\begin{abstract}
This study investigated the inhibitory effects of sea mustard on high-fat diet-induced obesity and hyperlipidemia in Sprague-Dawley rats. Sea mustard (Undaria pinnatifida) powder, sea mustard ethanol extract, and sea mustard ethanol-extracted residue were tested. The ethanol extracted residue had the most beneficial anti-hyperlipidemic activity. Alginate in the sea mustard was considered to be the key component. The ethanol-extracted residue of sea mustard also had antioxidant activity, which may be effective in preventing hyperlipidemia by increasing the enzymatic activity of superoxide dismutase, which can remove active oxygen from the bloodstream.
\end{abstract}

Key words: Anti-obesity, Antioxidant, Anti-hyperlipidemic, Alginate

\section{Introduction}

Improved standards of living have led to increased intake of saturated animal fat, which is associated with a variety of health disorders. As a result of nutritional imbalance, the occurrence of circulatory diseases, including high blood pressure and arteriosclerosis, has increased. The most noticeable change has been an increase in the proportion of cholesterol in the form of low-density lipoprotein (LDL), which can account for 60 to $70 \%$ of total cholesterol. High levels of LDL cholesterol may result from a deficiency of LDL receptors, an excess of apolipoprotein (Apo), or an increase of chylomicrons and very low-density lipoproteins (VLDL), which are induced by a diet rich in triglycerides (Hong et al., 1998). Keith (1991) reported that hypercholesterolemia is clinically recognized as the most important atherosclerosis risk factor. Dietary fiber is effective in preventing and reversing circulatory system diseases caused by a high-fat diet, because fiber hinders the absorption of cholesterol and neutral fats (Spiller and Amen, 1975). In the past, seaweed has not been considered as a valuable dietary component; it contains large amounts of

*Corresponding author: csykang@gwnu.ac.kr indigestible polysaccharides and therefore is a poor energy source. However, recent research has suggested that eating seaweed may have health benefits (Kim et al., 1988; Lee, 1996; Park et al., 1996; Kim and Kim, 1998). Seaweed has been shown to contain soluble fiber that can lower serum lipid levels (Kim et al., 1988), and this finding has prompted much research interest.

Sea mustard, a type of seaweed, is an alkaline health food that contains abundant active physiological substances such as $\mathrm{Na}, \mathrm{K}, \mathrm{Ca}, \mathrm{Mg}, \mathrm{P}, \mathrm{S}$, dietary fiber, linoleic acid, and vitamins (Anderson and Trityen-Clark, 1986; Anderson and Gustafson, 1988). In particular, alginic acid, the mucopolysaccharide in sea mustard, is effective in discharging heavy metal and radioactive substances from the body and in decreasing cholesterol, as well as preventing obesity, constipation, high blood pressure, and glycosuria (Choi et al., 1991; Kim and Kim, 1982; Kim and Cheong, 1984). Fucoidan extracted from sea mustard may also have beneficial effects with regard to cancer, cholesterol, blood coagulation, blood pressure, and lipid metabolism. Although sea mustard contains other biologically active components, including calcium and mucopolysaccharides, fucoidan is the component that hinders the growth of tumor cells such as sarcoma 180, L-1210, meth A, and B-16 melanoma (Sato et al., 
2002; Suetsuna et al., 2004; Yamamoto et al., 1984; Yamamoto et al., 1981).

In this study, we verified the effects of sea mustard on hyperlipidemia in Sprague-Dawley rats. We administered sea mustard powder, an ethanol extract of sea mustard, and the ethanol-extracted residue of sea mustard to evaluate their anti-hyperlipidemic, anti-arteriosclerotic, and antioxidant activities.

\section{Materials and Methods}

\section{Sea mustard sample preparation}

Sea mustard (Undaria pinnatifida) used in this study was collected and dried by Donghae Seaside, and was purchased from Chumunjin fish market in Korea. Animals were administered dried sea mustard powder, its ethanol extract, or the ethanol-extracted residue. To prepare the extract and residue, $100 \mathrm{~g}$ of dried sea mustard powder was mixed with $500 \mathrm{~mL}$ of $95 \%$ ethanol (5-fold the sample weight) in a 1,000 $\mathrm{mL}$ Erlenmeyer flask, followed by sonication (Powersonic 520; Hwashin, Korea) for $30 \mathrm{~min}$ at $30^{\circ} \mathrm{C}$. The extract was filtered through Whatman No. 2 filter paper, concentrated, frozen, dried on a rotary evaporator (Rotavator R-200; Buchi, Switzerland), and stored at $-40^{\circ} \mathrm{C}$.

\section{Experimental animals}

Male Sprague-Dawley rats $(140 \pm 10 \mathrm{~g})$, provided by Hyochang Science, Daegu, Korea, were divided into six groups of five rats each. The animals were housed at a relative humidity of $50 \pm 10 \%$ and a temperature of $22 \pm 3^{\circ} \mathrm{C}$, with a $12 \mathrm{~h}$ light $(07: 00$ 19:00)/dark cycle throughout the experiment (Tecniplast, Italy). A 1-week adaptation period was allowed before the experiment began, and only healthy animals were used for the experiment. The rats were provided with a normal basal diet, or a diet that caused hyperlipidemia along with a sea mustard preparation. Water was provided freely, but diet intake was measured. Each rat was orally administered $200 \mathrm{mg} / \mathrm{kg}$ of a sea mustard sample every day for 6 weeks. During $24 \mathrm{~h}$ before the experiment, only water was offered to the animals. Animals were sacrificed at a fixed time (10:00-12:00).

\section{Induction of hyperlipidemia by a high-fat diet}

Compositions of the normal and high-fat diets used in this study are shown in Table 1. Preliminary experiments had demonstrated that hyperlipidemia was induced in the rats after 6 weeks of the high-fat diet. The rats were fasted for $8 \mathrm{~h}$ after the final Table 1. Composition of basal and hyperlipidemic diet

\begin{tabular}{lcc}
\hline Ingredient & $\begin{array}{c}\text { Basal diet } \\
(\%)\end{array}$ & $\begin{array}{c}\text { Hyperlipidemic diet } \\
(\%)\end{array}$ \\
\hline Casein & 20.0 & 20.0 \\
DL-Methionine & 0.3 & 0.3 \\
Corn starch & 15.0 & 15.0 \\
Sucrose & 50.0 & 34.5 \\
Fiber $^{1)}$ & 5.0 & 5.0 \\
Corn oil $_{\text {AIN-mineral mixture }}^{2)}$ & 5.0 & - \\
AIN-vitamin mixture $^{3)}$ & 3.5 & 3.5 \\
Choline bitartate $_{\text {Beef tallow }}$ & 1.0 & 1.0 \\
\hline
\end{tabular}

${ }^{1)}$ Cellulose : Sigma Co. LTD., USA.

${ }^{2)}$ Mineral mixture based on the pattern of Rogers and Haper (1965) contain the following ( $/ \mathrm{kg}$ diet): calcium phosphate dibasic 500.0, sodium chloride 74.0 , potassium citrate monohydrate 220.0 , potassium sulfate 52.0, magnesium oxide 24.0, magnesium carbonate 3.5 , ferric citrate 6.0 , zinc carbonate 1.6 , cupuric carbonate 0.3 , potassium iodate 0.01 , chromium potassium sulfate 0.55 , sucrose, finely powered make 1,000 .

${ }^{3)}$ Vitamin mixture $(\mathrm{g} / \mathrm{kg}$ diet): thiamine $\mathrm{HCl} \mathrm{0.6}$, biotin 0.02 , riboflavin 0.6 , cyanocobalamine 0.001 , pyridoxine $\mathrm{HCl} 0.7$, retinyl acetate 0.8 , nicotinic acid 3.0, DL-tocopherol 3.8, Ca-pantothenate 1.6, 7-dehydrocholesterol 0.0025 , folic acid 0.2 , methionine 0.005 , sucrose, finely powered make 1,000 .

treatment and then anesthetized with $\mathrm{CO}_{2}$. Blood samples were collected from the abdominal aorta [the heart] using non-heparinized syringes and incubated in ice water for $30 \mathrm{~min}$. Serum was separated by centrifugation at $3,000 \mathrm{rpm}$ for $10 \mathrm{~min}$ at $4{ }^{\circ} \mathrm{C}$ and preserved at $-70^{\circ} \mathrm{C}$.

\section{Measurement of body and fatty tissue weights}

Body weight was measured every week throughout the experiment. Abdominal fat pad weight was determined by weighing the retroperitoneal and epididymal adipose tissues removed after the animals were sacrificed.

\section{Measurement of lipids in hepatic tissue and feces}

After being removed and weighed, hepatic tissues were kept in a $-70^{\circ} \mathrm{C}$ freezer, and 4 days of feces were collected. Neutral fat and cholesterol were extracted according to Folch et al. (1957).

\section{Measurement of total blood lipid content}

Total blood lipids were measured using a colorimetric method that relies on sulfo-phosphovanillin reaction principles (Fringe and Dunn, 1980). Samples were heated with sulfuric acid and reacted with vanillin phosphoric acid, leading to a loss of 
pink color detectable at $540 \mathrm{~nm}$. The results are expressed as milligrams per deciliter.

\section{Measurement of total cholesterol level}

Total serum cholesterol was measured using an AM 202-K assay kit according to the manufacturer's instructions (Asan Pharm. Co., Korea) and the method of Richmond (1976). Briefly, $3 \mathrm{~mL}$ of assay solution (cholesterol esterase $20.5 \mathrm{U} / \mathrm{L}$, cholesterol oxidase $10.7 \mathrm{U} / \mathrm{L}$, sodium hydroxide $1.81 \mathrm{~g} / \mathrm{L}$, potassium phosphate monobasic $13.6 \mathrm{~g} / \mathrm{L}$, phenol $1.88 \mathrm{~g} / \mathrm{L}$ ) were mixed with $20 \mu \mathrm{L}$ of serum sample and incubated at $37^{\circ} \mathrm{C}$ for $5 \mathrm{~min}$. The absorbance of the reaction mixture was measured at $500 \mathrm{~nm}$, and the total cholesterol level was calculated from a standard calibration curve.

\section{Measurement of triglyceride level}

Triglycerides were measured using an AM 157S-K assay kit according to the manufacturer's instructions (Asan Pharm. Co., Korea) and the method of McGowan et al. (1983). Briefly, $3 \mathrm{~mL}$ of assay solution (lipoprotein lipase 10,800 U, glycerol kinase $5.4 \mathrm{U}$, peroxidase $135,000 \mathrm{U}, \mathrm{L}-\alpha$-glycero phosphooxidase $160 \mathrm{U}, \mathrm{N}, \mathrm{N}-\mathrm{bis}(2-h y d r o x y e t h y l)-2$-aminomethane sulfonic acid $0.427 \mathrm{~g} / \mathrm{dL}$ ) were mixed with 20 $\mu \mathrm{L}$ of serum sample and incubated at $37^{\circ} \mathrm{C}$ for $10 \mathrm{~min}$. The absorbance of the reaction mixture was measured at $550 \mathrm{~nm}$, and the total triglyceride level was calculated from a standard calibration curve.

\section{Measurement of phospholipid level}

Phospholipids were measured using an assay kit according to the manufacturer's protocol (Iatron Chem. Co., Tokyo, Japan) and the method of Chen et al. (1979).

\section{Measurement of high-density lipoprotein (HDL)- cholesterol level}

Serum HDL-cholesterol was measured using an AM 203-K assay kit according to the manufacturer's protocol (Asan Pharm. Co., Korea) and the method of Noma et al. (1986). Briefly, $20 \mu \mathrm{L}$ of serum sample were mixed with $200 \mu \mathrm{L}$ of a solution containing $0.1 \%$ dextran sulfate and $0.1 \mathrm{M}$ magnesium chloride, and incubated at room temperature for $10 \mathrm{~min}$ After centrifugation at $2,500 \times \mathrm{g}$ for $10 \mathrm{~min}, 100 \mu \mathrm{L}$ of the supernatant were mixed with $3 \mathrm{~mL}$ of assay solution (lipoprotein lipase 10,800 U, glycerol kinase $5.4 \mathrm{U}$, peroxidase $135,000 \mathrm{U}, \mathrm{L}-\alpha$-glycero phosphooxidase $160 \mathrm{U}, \mathrm{N}, \mathrm{N}$-bis(2-hydroxyethyl)-2-aminomethane sulfonic acid $0.427 \mathrm{~g} / \mathrm{dL}$ ) and incubated at $37^{\circ} \mathrm{C}$ for 5 min. The absorbance of the reaction mixture was measured at $500 \mathrm{~nm}$, and the results were calculated in milligrams per deciliter from a standard calibration curve.

\section{Calculation of low density lipoprotein (LDL)- cholesterol level}

The LDL-cholesterol level was calculated using the equation of Friedewald et al. (1972):

$$
\begin{aligned}
& \mathrm{LDL} \text { cholesterol }=\text { total cholesterol- } \\
& \quad(\text { HDL-cholesterol + triglycerides/5). }
\end{aligned}
$$

\section{Measurement of lipid peroxidation}

Lipid peroxidation was measured in serum, according to the method of Yagi (1987). Serum was preincubated with $1 / 12 \mathrm{~N} \mathrm{HSO}$ and $10 \%$ phosphortungstic acid for $5 \mathrm{~min}$, and then centrifuged. The protein pellet obtained was resuspended in $1 / 12 \mathrm{~N}$ HSO and $10 \%$ phosphotungstic acid, and the procedure was repeated. The protein pellet was then suspended and incubated in $1 \mathrm{~mL}$ of distilled water with $0.67 \%$ thiobarbituric acid and $50 \%$ acetic acid at $95^{\circ} \mathrm{C}$ for $60 \mathrm{~min}$, after which $5 \mathrm{~mL}$ of $\mathrm{n}-\mathrm{BuOH}$ were added, and the mixture was allowed to stand at room temperature. The red $\mathrm{n}-\mathrm{BuOH}$ layer was separated by centrifugation for $10 \mathrm{~min}$, and its absorbance was measured using a fluorometer (excitation, $515 \mathrm{~nm}$; emission, $553 \mathrm{~nm}$ ). The malondialdehyde (MDA) concentration (nmol/mL of serum) was calculated from a standard curve.

\section{Measurement of hydroxyl radicals}

Hydroxyl radicals were measured in serum according to the method of Kobatake et al. (1987). Briefly, $333.3 \mu \mathrm{L}$ of a mixture composed of $34.8 \mu \mathrm{L}$ of serum, $0.54 \mathrm{M} \mathrm{NaCl}, 0.1 \mathrm{M}$ potassium phosphate buffer (pH 7.4), $10 \mathrm{nM} \mathrm{NaN}_{3}, 7 \mathrm{nM}$ deoxyribose, 5 $\mathrm{nM}$ ferrous ammonium sulfate, and distilled water was mixed on a vortexer and incubated at $37^{\circ} \mathrm{C}$ for 15 min. After $67 \mu \mathrm{L}$ of this sample were mixed with 75 $\mu \mathrm{L}$ of $8.1 \%$ sodium dodecyl sulfate, $67 \mu \mathrm{L}$ of $20 \%$ acetic acid, and distilled water, $222 \mu \mathrm{L}$ of $1.2 \%$ thiobarbituric acid were added. The final solution was boiled for $30 \mathrm{~min}$, cooled to room temperature, and clarified by centrifugation at $700 \times \mathrm{g}$ for $5 \mathrm{~min}$. Absorbance of the supernatant was determined at 532 $\mathrm{nm}$, and the concentration of hydroxyl radical (nmol/mg protein) was calculated from a standard curve.

\section{Measurement of superoxide dismutase (SOD) activity}

Superoxide dismutase activity was determined in serum using the method of Oyanagui (1984). Serum was diluted 100 -fold with potassium phosphate buffer, 
and $100 \mu \mathrm{L}$ of the diluted sample were placed into a test tube. Then, $200 \mu \mathrm{L}$ of solution A (3 nM hydroxylamine $/ 3 \mathrm{nM}$ hypoxanthine), $200 \mu \mathrm{L}$ of solution B $(7.5 \mathrm{mU} / \mathrm{mL}$ xanthine oxidase with $0.1 \mathrm{mM}$ EDTA$\mathrm{Na}_{2}$ ), and $500 \mu \mathrm{L}$ of distilled water were added. The solutions were mixed on a vortexer and incubated at $37^{\circ} \mathrm{C}$ for $40 \mathrm{~min}$. Finally, $2 \mathrm{~mL}$ of solution $\mathrm{C}(300 \mathrm{mg}$ of sulfanilic acid/5.0 mg N-1-naphtyl-ethylenediamine in $500 \mathrm{~mL}$ of $16.7 \%$ acetic acid) were added, and the mixture was allowed to stand at room temperature for $20 \mathrm{~min}$. The absorbance of the sample was measured at $550 \mathrm{~nm}$, and SOD activity was calculated from a standard curve.

\section{Measurement of protein content}

Protein content was determined by the method of Lowry et al. (1951).

\section{Statistical analysis}

Means and standard deviations of data from individual experiments were calculated. Significant differences between individual experiments were determined using Duncan's multiple range test. Values of $p \leq 0.05$ were taken to indicate statistical significance.

\section{Results and Discussion}

\section{Anti-obesity effect}

Table 2 shows body weight changes in the rats with diet-induced hyperlipidemia after the addition of sea mustard to their diets. In rats receiving sea mustard ethanol extract, the weight decreased in weeks 1 and 2 . By week 6 , body weight had declined in rats fed all three sea mustard preparations (powder, ethanol extract, and ethanol-extracted residue) compared with the control group. The rate of weight decrease was greatest for the rats receiving ethanol-extracted residue.

This finding suggests that the anti-obesity properties of sea mustard are not attributable exclusively to ethanol-soluble components, but rather it is likely that the fiber in the ethanol-extracted residue also contributed to the anti-obesity effect. This is contrary to results reported by Maeda et al. (2005), who found that fucoxanthin in sea mustard was responsible for its anti-obesity properties. On the other hand, Lee et al. (1996) reported that a group of diabetic rats fed sea mustard showed a tendency toward weight gain, compared with the diabetic control group.

\section{Fluctuation of fatty tissue weight}

Table 3 shows the effects of the sea mustard preparations on the weight of fatty tissues in the rats. The quantities of retroperitoneal lipids in rats fed sea mustard powder, ethanol extract, and ethanolextracted residue were $12.3 \pm 1.3,14.5 \pm 2.4$, and $10.3 \pm 1.4 \mathrm{mg} / \mathrm{g}$, respectively, compared with the control group $(14.9 \pm 2.1)$. On the other hand, the weight of epididymal lipids in rats fed ethanol-

Table 2. Effect of sea mustard on the body weight in rats fed a normal and hyperlipidemic diet for 6 weeks

\begin{tabular}{|c|c|c|c|c|c|c|c|}
\hline \multirow{2}{*}{ Treatment } & \multirow{2}{*}{$\begin{array}{c}\text { Dose } \\
(\mathrm{mg} / \mathrm{kg})\end{array}$} & 1 & 2 & 3 & 4 & 5 & 6 (Weeks) \\
\hline & & \multicolumn{6}{|c|}{ Body weight gain (g) } \\
\hline Normal & & $69.7 \pm 8.3^{b}$ & $117.9 \pm 10.6^{b}$ & $138.5 \pm 19.4^{\mathrm{e}}$ & $181.7 \pm 29.6^{\mathrm{b}}$ & $211.7 \pm 27.2^{f}$ & $220.8 \pm 28.6^{f}$ \\
\hline Control & & $88.5 \pm 9.5^{a}$ & $161.3 \pm 21.3^{\mathrm{a}}$ & $221.7 \pm 30.5^{\mathrm{abc}}$ & $251.2 \pm 21.1^{\mathrm{a}}$ & $306.8 \pm 20.5^{\mathrm{ab}}$ & $331.7 \pm 31.7^{\mathrm{a}}$ \\
\hline Sea mustard powder & 200 & $83.9 \pm 7.2^{\mathrm{a}}$ & $165.5 \pm 19.8^{\mathrm{a}}$ & $198.3 \pm 18.6^{\mathrm{bcd}}$ & $236.5 \pm 20.6^{\mathrm{a}}$ & $281.3 \pm 19.1^{\text {bcde }}$ & $293.6 \pm 24.5^{\text {bcde }}$ \\
\hline Ethanol extracts & 200 & $81.8 \pm 8.6^{\mathrm{a}}$ & $154.7 \pm 18.7^{\mathrm{a}}$ & $210.4 \pm 17.2^{\mathrm{abcd}}$ & $249.7 \pm 19.4^{a}$ & $294.8 \pm 18.3^{\mathrm{abcd}}$ & $300.7 \pm 19.8^{\mathrm{bcd}}$ \\
\hline Ethanol extracted residues & 200 & $90.3 \pm 9.4^{\mathrm{a}}$ & $160.2 \pm 20.8^{a}$ & $195.6 \pm 21.3^{\mathrm{cd}}$ & $226.9 \pm 18.8^{a}$ & $274.5 \pm 19.5^{\text {cde }}$ & $281.2 \pm 18.6^{\text {de }}$ \\
\hline
\end{tabular}

Values are mean \pm S.D. for six experiments. Values followed by the same letter are not significantly different $(P<0.05)$.

Table 3. Abdominal fat pad weight in the normal and fat diet-induced rats fed sea mustard for 4 weeks

\begin{tabular}{|c|c|c|c|}
\hline \multirow{2}{*}{ Treatment } & \multirow{2}{*}{ Dose $(\mathrm{mg} / \mathrm{kg})$} & Retroperitoneal & Epididymal \\
\hline & & \multicolumn{2}{|c|}{$\mathrm{mg} / \mathrm{g}$ body weight } \\
\hline Normal & & $6.3 \pm 3.2^{f}$ & $7.8 \pm 2.0^{f}$ \\
\hline Control & & $14.9 \pm 2.1^{\mathrm{a}}$ & $12.4 \pm 1.4^{\mathrm{abc}}$ \\
\hline Sea mustard powder & 200 & $12.3 \pm 1.3^{\mathrm{bcd}}$ & $11.9 \pm 1.0^{\mathrm{abcd}}$ \\
\hline Sea mustard ethanol extracts & 200 & $14.5 \pm 2.4^{\mathrm{bc}}$ & $13.1 \pm 1.1^{\mathrm{a}}$ \\
\hline Ethanol extracts sea mustard residues & 200 & $10.3 \pm 1.4^{\mathrm{de}}$ & $10.4 \pm 1.0^{\text {de }}$ \\
\hline
\end{tabular}

Values are mean \pm S.D. for six experiments. Values followed by the same letter are not significantly different $(P<0.05)$. 
extracted residue was $10.4 \pm 1.0 \mathrm{mg} / \mathrm{g}$, which is $16 \%$ less than that of the control group $(12.4 \pm 1.4 \mathrm{mg} / \mathrm{g})$. These results indicate that ethanol-extracted residue is more effective than the other two preparations in reducing lipid storage, probably owing to its fiber content, which includes alginic acid.

\section{Change of serum lipid components}

Table 4 shows the concentrations of lipid components in the sera of rats fed the sea mustard preparations. In rats fed ethanol-extracted residue, the concentration of phospholipids was $131.3 \pm 11.5$ $\mathrm{mg} / \mathrm{dL}$, which is a decrease of $11.7 \%$ compared with the control group $(148.7 \pm 10.2 \mathrm{mg} / \mathrm{dL})$. Serum triglyceride concentrations in the rats fed sea mustard

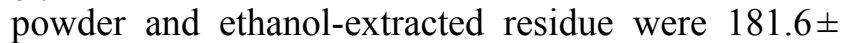
$11.8 \mathrm{mg} / \mathrm{dL}$ and $167.4 \pm 12.5 \mathrm{mg} / \mathrm{dL}$, respectively, which are $9.3 \%$ and $16.4 \%$ lower, respectively, than the control value $(200.3 \pm 12.4 \mathrm{mg} / \mathrm{dL})$.

George et al. (1982) reported that fiber combining with bile salts inhibits lipid absorption and directly accounts for most of the decrease in lipid levels caused by fiber intake. Akiba and Matsumoto (1982) reported that fiber decreases the concentration of serum phospholipids. Furthermore, Goode et al. (1995) found that the lipid content of the serum has an intimate interrelation with blood pressure, and that patients with high blood pressure have a higher total lipid content in the serum. The results of this experiment suggest that a sea mustard diet may be effective in improving hyperlipidemia.

\section{Changes of serum cholesterol content and athero- sclerosis indices}

Table 5 shows the effect of the sea mustard preparations on serum cholesterol content and atherosclerosis indices in the rats. The serum total cholesterol concentration in rats with diet-induced hyperlipidemia was $91.6 \pm 5.2 \mathrm{mg} / \mathrm{dL}$. However, total cholesterol decreased to $83.6 \pm 6.1 \mathrm{mg} / \mathrm{dL}(8.7 \%$ decrease) or $76.8 \pm 4.3 \mathrm{mg} / \mathrm{dL}(16.2 \%$ decrease $)$ in rats fed sea mustard powder or ethanol-extracted residue, respectively. Conversely, HDL-cholesterol increased to $35.6 \pm 1.2 \mathrm{mg} / \mathrm{dL}$, an $11.9 \%$ increase from $\mathrm{t}$ the control group $(31.8 \pm 1.2 \mathrm{mg} / \mathrm{dL})$. LDLcholesterol was $7.6 \pm 0.9 \mathrm{mg} / \mathrm{dL}$ in rats with dietinduced hyperlipidemia. After administering sea mustard powder, ethanol extract, or ethanol-extracted residue, it had decreased to $7.2 \pm 0.8,7.5 \pm 0.7$, or $6.7 \pm 0.7 \mathrm{mg} / \mathrm{dL}$, respectively. It has been reported that fiber decreases lipid absorption in the intestine and increases bile acid excretion, while also promoting bile acid synthesis from cholesterol, thus further decreasing the cholesterol concentration. Short-chain fatty acids, which are produced and act in the large intestine, hinder the synthesis of endogenous cholesterol (Chen and Anderson, 1979; Story, 1981; Anderson and Bridges, 1984; Nishina and Freedland, 1990; Schrijver et al., 1992). In particular, water soluble fibers such as pectin, gums, mucilages, and sea algae polysaccharides decrease the concentrations of total cholesterol and LDL-cholesterol, while increasing the concentration of HDL-

Table 4. Effect of sea mustard on the concentration of serum lipids in rats fed a hyperlipidemic diet for 4 weeks

\begin{tabular}{|c|c|c|c|}
\hline \multirow{2}{*}{ Treatment } & \multirow{2}{*}{ Dose (mg/kg) } & Phospholipid & Triglyceride \\
\hline & & \multicolumn{2}{|c|}{$\mathrm{mg} / \mathrm{dL}$} \\
\hline Normal & & $120.4 \pm 14.6^{d}$ & $68.7 \pm 7.26^{\dagger}$ \\
\hline Control & & $148.7 \pm 10.2^{a}$ & $200.3 \pm 12.4^{a}$ \\
\hline Sea mustard powder & 200 & $138.8 \pm 11.7^{\mathrm{abc}}$ & $181.6 \pm 11.8^{\mathrm{bc}}$ \\
\hline Ethanol extracts & 200 & $142.5 \pm 12.3^{\mathrm{abc}}$ & $190.5 \pm 10.7^{\mathrm{ab}}$ \\
\hline Ethanol extracted residues & 200 & $131.3 \pm 11.5^{\mathrm{bcd}}$ & $167.4 \pm 12.5^{\mathrm{de}}$ \\
\hline
\end{tabular}

Values are mean \pm S.D. for six experiments. Values followed by the same letter are not significantly different $(P<0.05)$.

Table 5. Effect of sea mustard on serum cholesterol and AI in rats fed a hyperlipidemic diet for 4 weeks

\begin{tabular}{|c|c|c|c|c|c|}
\hline \multirow{2}{*}{ Treatment } & \multirow{2}{*}{ Dose $(\mathrm{mg} / \mathrm{kg})$} & \multicolumn{4}{|c|}{ Cholesterol (mg/dL) } \\
\hline & & Total & $\mathrm{HDL}$ & LDL & $\mathrm{Al}$ \\
\hline Normal & & $56.8 \pm 6.3^{9}$ & $41.6 \pm 2.4^{\mathrm{a}}$ & $2.6 \pm 0.6^{a}$ & $0.4 \pm 0.1^{\mathrm{h}}$ \\
\hline Control & & $91.6 \pm 5.2^{\mathrm{a}}$ & $31.8 \pm 1.2^{f}$ & $7.6 \pm 0.9^{b}$ & $1.9 \pm 0.2^{\mathrm{a}}$ \\
\hline Sea mustard powder & 200 & $83.6 \pm 6.1^{\mathrm{cd}}$ & $35.4 \pm 2.2^{\text {def }}$ & $7.2 \pm 0.8^{\mathrm{bc}}$ & $1.4 \pm 0.1^{\mathrm{de}}$ \\
\hline Ethanol extracts & 200 & $90.5 \pm 4.2^{\mathrm{ab}}$ & $33.5 \pm 1.2^{\mathrm{def}}$ & $7.5 \pm 0.7^{\mathrm{b}}$ & $1.7 \pm 0.1^{b}$ \\
\hline Ethanol extracted residues & 200 & $76.8 \pm 4.3^{\mathrm{ef}}$ & $35.6 \pm 1.2^{\mathrm{bc}}$ & $6.7 \pm 0.7^{\mathrm{a}}$ & $1.2 \pm 0.1^{\dagger}$ \\
\hline
\end{tabular}

Values are mean \pm S.D. for six experiments. Values followed by the same letter are not significantly different $(P<0.05)$. AI $($ Atherosclerosis Index $)=($ total cholesterol - HDL cholesterol $) /$ HDL cholesterol. 
cholesterol (Yang et al., 1996; Park et al., 1994; Kang et al., 1994; Fernandez et al., 1990). Furthermore, it has been reported that a diet including a sea mustard or laver mixture remarkably decreased serum cholesterol in diabetic rats (Lee et al., 1996). In particular, diets containing carrageenan, a watersoluble polysaccharide found in red algae, have been found to decrease cholesterol concentrations (Tsai et al., 1976; Jang and Park, 1995).

Our study demonstrated an effect on total cholesterol caused by ingestion of sea mustard powder and sea mustard ethanol extract, and HDLand LDL-cholesterol levels were modified by consumption of ethanol-extracted residue. These results show that the addition of sea mustard is effective in improving hyperlipidemia. Moreover, atherosclerosis indices in rats fed sea mustard powder, ethanol extract, and ethanol-extracted residue were $1.4 \pm 0.1,1.7 \pm 0.1$, and $1.2 \pm 0.1 \mathrm{mg} / \mathrm{dL}$, representing decreases of $27.6 \%, 9.6 \%$, and $38.8 \%$, respectively, compared with rats having diet-induced hyperlipidemia (index, $1.9 \pm 0.2 \mathrm{mg} / \mathrm{dL}$ ).

\section{Changes of lipid and cholesterol contents of hepatic tissue}

When cholesterol is fed to rats, the serum free cholesterol concentration increases (Chung et al., 1988). On the other hand, the total cholesterol/ cholesteryl ester consistency ratio is normally 64$72 \%$ in humans, but it declines with hepatotoxicity and rises with hypercholesterolemia (Jang and Park, 1995). Excess fatty acids from a high-fat diet are converted into triglycerides in the liver, and when the hepatic lipids are not removed, a fatty liver condition can develop (Yang et al., 1996). The cholesterol concentration in the liver is an important indicator of circulatory system diseases, as the liver delivers cholesterol to the blood in the form of soluble or ester-type cholesterol (Choi et al., 1987). Table 6 shows the effect of the sea mustard preparations on the hepatic lipid concentration and cholesterol content in rats with diet-induced hyperlipidemia. The total lipid concentrations in rats fed sea mustard powder and ethanol-extracted residue were $31.4 \pm 1.4$ $\mathrm{mg} / \mathrm{g}(10 \%$ lower than control) and $30.2 \pm 1.2 \mathrm{mg} / \mathrm{g}$ (13.5\% lower than control), respectively. The triglyceride level in rats fed ethanol-extracted residue was $24.3 \pm 1.8 \mathrm{mg} / \mathrm{g}, 7.9 \%$ lower than the control value $(26.4 \pm 2.1 \mathrm{mg} / \mathrm{g})$. These results imply that the addition of sea mustard to the diet can affect the disease state of an animal, indirectly demonstrating its effect on hyperlipidemia.

\section{Change of MDA concentration in hepatic tissue}

Table 7 shows the effect of the sea mustard preparations on lipid peroxidation, measured as

Table 6. Effect of sea mustard on the hepatic lipid concentration of hepatic tissue of rat fed a hyperlipidemic diet for 4 weeks

\begin{tabular}{|c|c|c|c|c|}
\hline \multirow{2}{*}{ Treatment } & \multirow{2}{*}{ Dose (mg/kg) } & Total lipid & Triglyceride & Cholesterol \\
\hline & & \multicolumn{3}{|c|}{$\mathrm{mg} / \mathrm{g}$ of tissue } \\
\hline Normal & & $16.8 \pm 2.0^{f}$ & $9.4 \pm 1.0^{d}$ & $2.6 \pm 0.5^{b}$ \\
\hline Control & & $34.9 \pm 2.2^{a}$ & $26.4 \pm 2.1^{\mathrm{a}}$ & $6.3 \pm 0.4^{\mathrm{a}}$ \\
\hline Sea mustard powder & 200 & $31.4 \pm 1.4^{\mathrm{cd}}$ & $25.2 \pm 2.0^{\mathrm{abc}}$ & $6.2 \pm 0.5^{\mathrm{a}}$ \\
\hline Ethanol extracts & 200 & $33.7 \pm 1.3^{\mathrm{ab}}$ & $26.2 \pm 1.7^{\mathrm{ab}}$ & $6.2 \pm 0.5^{\mathrm{a}}$ \\
\hline Ethanol extracted residues & 200 & $30.2 \pm 1.2^{\mathrm{de}}$ & $24.3 \pm 1.8^{\mathrm{bc}}$ & $6.0 \pm 0.6^{a}$ \\
\hline
\end{tabular}

Values are mean \pm S.D. for six experiments. Values followed by the same letter are not significantly different $(P<0.05)$.

Table 7. Effect of sea mustard on thiobarbituric acid(TBARS) concentration of hepatic homogenate of rats fed hyperlipidemic diet for 4 weeks

\begin{tabular}{lcc}
\hline Treatment & Dose $(\mathrm{mg} / \mathrm{kg})$ & Thiobarbituric acid (TBARS) \\
\cline { 3 - 3 } & & MDA $\mathrm{nmol} / \mathrm{mL}$ serum \\
Normal & & $26.9 \pm 3.6^{\mathrm{h}}$ \\
Control & 200 & $52.4 \pm 2.2^{\mathrm{a}}$ \\
Sea mustard powder & 200 & $45.8 \pm 3.1^{\mathrm{de}}$ \\
Ethanol extracts & 200 & $49.6 \pm 2.6^{\mathrm{ab}}$ \\
Ethanol extracts sea mustard residues & & $40.7 \pm 2.0^{\dagger}$ \\
\hline
\end{tabular}

Values are mean \pm S.D. for six experiments. Values followed by the same letter are not significantly different $(P<0.05)$. 
thiobarbituric acid reactive substances (TBARS) and

Table 8. Effect of the sea mustard on the serum hydroxyl radical and superoxide dismutase(SOD) activities in rats fed hyperlipidemic diet 4 weeks

\begin{tabular}{lccc}
\hline \multirow{2}{*}{ Treatment } & \multirow{2}{*}{ Dose $(\mathrm{mg} / \mathrm{kg})$} & Hydroxy radical & SOD activity \\
\cline { 3 - 4 } & & nmol/mg protein & Unit/mg protein \\
\hline Normal & & $3.0 \pm 0.4^{\mathrm{e}}$ & $3.5 \pm 0.3^{\mathrm{a}}$ \\
Control & 200 & $5.9 \pm 0.3^{\mathrm{a}}$ & $1.7 \pm 0.2^{\mathrm{bcd}}$ \\
Sea mustard powder & 200 & $5.2 \pm 0.2^{\mathrm{cd}}$ & $1.8 \pm 0.1^{\mathrm{bcd}}$ \\
Ethanol extracts & 200 & $5.7 \pm 0.3^{\mathrm{ab}}$ & $1.7 \pm 0.1^{\mathrm{bcd}}$ \\
Ethanol extracts sea mustard residues & $5.2 \pm 0.3^{\mathrm{cd}}$ & $1.8 \pm 0.2^{\mathrm{bc}}$
\end{tabular}

Values are mean \pm S.D. for six experiments. Values followed by the same letter are not significantly different $(P<0.05)$.

Unit: on unit of SOD was defined as the which inhibited the reduced of alkaline.

DMSO-mediated adrechrome by $50 \%$ in one $\mathrm{ml}$ of blood.

Thiobarbituric acid reactive substances (TBARS) and expressed as MDA equivalents, in hepatic tissue of rats with diet-induced hyperlipidemia. The MDA concentrations in rats fed sea mustard powder $(45.8 \pm$ $3.1 \mathrm{nmol} / \mathrm{mL}$ ) and ethanol-extracted residue $(40.7 \pm$ $2.0 \mathrm{nmol} / \mathrm{mL}$ ) were $12.6 \%$ and $22.3 \%$ lower the control value $(52.4 \pm 2.2 \mathrm{nmol} / \mathrm{mL})$, respectively. Lipid peroxidation produces cell damage and may contribute to cancer, atherosclerosis, and aging (Cho and Bang, 2004). The increased oxidative stress associated with lipid peroxidation in tissues may also be reduced by the consumption of sea mustard. Increases in the MDA content of kidney and liver have been reported by Celik et al. (2002), and Velthuis-te et al. (1996) have reported similar findings.

\section{Change of serum hydroxyl radical and superoxide dismutase activities}

Table 8 shows the effect of the sea mustard preparations on serum hydroxyl radical and superoxide dismutase activities in the rats. The hydroxyl radical concentration in the groups fed sea mustard powder and ethanol-extracted residue was 5.2 $\mathrm{nmol} / \mathrm{mg}$, which was $12 \%$ lower than that in the control group $(5.9 \pm 0.3 \mathrm{nmol} / \mathrm{mg})$. Superoxide dismutase activity was notably different between the control group and the group fed sea mustard ethanol extract; however, no effects were observed in the rats fed sea mustard powder or ethanol-extracted residue.

Our results suggest that the ethanol-extracted residue of sea mustard may be a functionally beneficial food owing to its anti-obesity, antioxidant, anti-hyperlipidemic, and anti-arteriosclerotic effects.

\section{Acknowledgments}

This work was supported by the National Research Foundation of Korea(NRF) grant funded by the Korea government(MEST) (No.2009-0083-638).

\section{References}

Akiba Y and Matsumoto T. 1982. Effects of dietary fiver on lipie metabolism in liver and adipose tissue in chicks. J Nut 112, 1577-1585.

Anderson JW and Bridges SR. 1984. Sort-chain fatty acid fermentation products of plant fiver after glucose metabolism of isolated rat hepatocytes. Proc Soc Exp Biol Med 177. 372-376.

Anderson JW and Gustafson NJ. 1988. Hypocholesterolemic effects of bean products. Am J Clin Nutr 48, 749-753.

Anderson JW and Trityen-Clark J. 1986. Dietary fiber : Hyperlipidemia, hypertension, and coronary heart disease. Am J Gastroent 81, 907-919.

Celik S, Baydas G and Yilmaz O. 2002. Influence of vitamin $\mathrm{E}$ on the levels of fatty acids and MDA in sometisues of diabetic rats. Cell Biochem Funct 20, 6771.

Chen PS, Toribara TY and Warnerm H. 1956. Microdetermination of phosphorus. Anal Chem Vol. 1756-1760.

Chen WJ and Anderson JW. 1979. Effects of guar gum and wheat bran on lipid metabolism in rat. J Nutr 109, 1028-1034.

Choi JH, Kim JI, Kim IS and Yoon TH. 1991. Studies on Anti-aging Action of Brown Algae (Undaria pinnatifida) 1. Dose Effect of Alginic Acid as a Modulator of Anti-aging Action in Serum Lipids. Korean J Gerontology 1, 173-178.

Cho KJ, Lee YS and Ryu BH. 1990. Antitumor Effect and Immunology Activity of Seaweeds toward Sarcoma180. Bull Korean Fish Soc 23, 345-352.

Cho YJ and Bang MA. 2004. Effects of Dietary Seaweed 
on Blood Glucose, Lipid and Glutathione Enzymes in Streptozotocin-Induced Diabetic Rats. J Korean Soc Food Sic Nutr 33, 987-994.

Choi YS, Chung KH and Cho SH. 1987. Effects of Alcohol Consumption and Fat Content in Diet on Growth, Hepatic Function and Biochemical Indices of Blood in Rat. Korean J Nutr 20, 432-441.

Chung KH, Cho SH, Sin EN, Choi KH and Choi YS. 1988. Effects of Alcohol Consumption and Fat Content in Diet on Chemical Composition and Morphology of Liver in Rat. Korean J Nutr 21, 154-163.

Fernandez ML, Trejo A and McNamara DJ. 1990. Pectin isolated from prickly pear(Opuntiasp.)modifies low density lipoprotein metabolism in cholesterol-fed guinea pigs. J Nutr 120, 1238-1290.

Folch J, Lees M and Sloane Stanley GH. 1957. A simple method for the isolation and purification of total lipids from animal tissues, J Biol Chem 226, 497-509.

Friedwald WT, Levy RL and Fedreicson DS. 1972. Estimation of the concentration of low-density lipoprotein cholesterol in plasma, without was of the preparative ultracentrifuge. Clin Chem 18, 499-506.

Fringe CS and Dunn RM. 1980. The Colormetric method for determination of serum total lipids based on the sulfo-phosphanilli reaction. an J clin pathol 52, 82-92.

George VV, Timothy MS and Linda LG. 1982. Effects of cholesterol absorption, synthesis and metabolism in the rats. Am J Chin Nutr 33, 2182-2191.

Goode GK, Miller JP and Heagerty AM. 1995. Hyperlipidemia, hypertension and coronary heart diseare. Lancet 345, 362-364.

Hong YK, Park IS, Jung YH, Song SH and Hong SY. 1998. Effect of the Seaweed Porphya yezoensis Extract on Triton WR-1339 Induced Hypercholesterolemia in Mouse. J Korean Fish Soc 31, 508-515.

Jang SJ and Park YJ. 1995. Effects of Dietary Fiber Sources and Levels on Lipid Metabolism in Rats fed High Lard Diet. Korean J Nutr 28, 107-114.

Kang HJ, Suh MJ and Song YS. 1994. Effects of Sodium Alginate and Cellulose on Postprandial Plasma Lipoprotein and Cholesterol Metabolism in Rats (I) J Korean Soc Food Nutr 23, 887-893.

Keith ES. 1991. Atherosclerosis. Encyclo Human Bio 1, 447-455.

Kim HS and Kim GJ. 1998. Effects of the Feeding Hijikia fusiforme(Harvey) Okamura on Lipid Composition of Serum in Dietary Hyperlipidemic Rats. J Korean Soc Food Sci Nutr 27, 718-723.

Kim KH and Cheong JJ. 1984. Optimum Conditions for Extracting Alginic Acid from Undaria Pinnatifida and Amino Acid Composition of Its Extraction Residue. Korean J Food Sci Technol 16, 336-340.

Kim KH and Kim CS. 1982. Studies on the Manufacture of
Underia pinnatifida Laver and it's Physicochemical Properties - I. Histochemical Properties. Korean J Food Sci Technol 14, 336-341.

Kim SH, Park HY and Park WK. 1988. Determination and physical properties of dietary fiber in seaweed products. J Korean Soc Food Nutr 17, 324-325.

Kobatake Y, Saito M, Kuroda K, Kobayashi S and Innami S. 1987. Influence of fish consumption on serum lipid and lipid peroxide concentrations in middle aged subjects. J Japan Soc Nutr \& Food Sci 40, 103-110.

Lee HS. 1996. A Study on the development of high-fiber supplements for the diabetic patients (I) -Effect of Seaweed Supplementation on the Gastrointestinal Function and Diabetic Symptom Control in Streptozotocin-induced Diabetic Rats. Korean J Nutr 29 , 286-295.

Lee HS, Lee YK, Choi MS, Park SH and Kim YJ. 1996. A Study on the development of high-fiber supplements for the diabetic patients (II) -Effect of Seaweed Supplementation on the Gastrointestinal Function and Diabetic Symptom Control in Streptozotocin-induced Diabetic Rats-. Korean J Nutr 29, 296-306.

Lee HS, Choi MS, Lee YK, Park SH and Kim YJ. 1996. A Study on the development of high-fiber supplements for the diabetic patients (II) Effect of Seaweed Supplymentation on the Lipid and Glucose Metabolism in Streptozotocin-induced Diabetic Rats. Korean J Nutr 29, 296-306.

Lowry OH, Rosebrough NJ, Farr AL, and Rardall RJ. 1951. Protein measurement with the folin phenol reagent. J Biol Chem 193, 265.

Maeda H, Hosokawa M, Sashima T, Funayama K and Miyashita K. 2005. Fucoxanthin from edible seaweed, Undaria pinnatifida, shows antiobesity effect through UCP1 expression in white adipose tissues. Biochemical and Biophysical Research Communications 332, 392-397.

Mc Gowan MW, Artiss JD and Stramdbergh DR. 1983. Aperoxidase -coupled method for the colorimetric determination of serum triglycerides. Clin Chem 29, 538.

Noma A, Matsushita S and Komori T. 1986. High-density lipoprotein cholesterol levels of very old people in the diagnosis of dementia. Oxford Journals 15, 267-270.

Nishina PM and Freedland RA. 1990. Effects of propionate on lipid bipsyntheses in isolated rat hepatocyres. J Nutr 120, 668-673.

Oyanagui Y. 1984. Reevaluation of assay methods and establishment of kit for superoxide dismutase activity. Anal Biochem 42, 290-296.

Park JC, Jang YI, Doo MS, Kim SH and Choi JW. 1996. Effect of Methanolic Extract of Pachymeniopsis elliptica on Lipids Component of Hyperlipidemic Rats. 
J Korean Soc Food Sci Nutr 25, 958-962.

Park SH, Lee YK and Lee HS. 1994. The Effect of Dietary Fiber Feeding on Gastrointestinal Functions and Lipid and Glucose Metabolism in Streptozotocin-induced Diabetic Rats. Korean J Nutr 27, 311-322.

Richmond W. 1976. Use of cholesterol oxidase for assay of total and free cholesterol in serum by continuous flow analysis. Clin Chem 22, 1579.

Sato M, Hosokawa T, Yamaguchi T, NaKano T, Muramoto $\mathrm{K}$ and Kahara T. 2002. Angiotensin I-converting enzyme inhibitory peptides derived from' Wakame (Undaria pinnatifida) and their antihypertensive effect in spontaneously hypersensitive rats. J Agtic Food Chem 50, 6245-6252.

Schrijver R, Fremaut D and Verheyen A. 1992. Cholesterollowwering effects and utillization of protein, lipid, fiver and energy in rats fed unprocessd and baked oat bran. J Nutr 122, 1318-1324.

Spiller GA and Amen RJ. 1975. Dietary fiber in human nutrition, Crit. Rev. Food Sci Nutr 7, 39-66.

Story JA. 1981. The role of dietary fiber in lipid metabolism. Adv Lipid Res 18, 229-246.

Suetsuna K, Kaekawa K and Chen JR. 2004. Antihypertensive effects of Undaria pinnatifida (Wakame) peptide on blood pressure on spontaneously hyper- tensive rats. J Nutr Biochem 15, 267-272.

Tsai AC, Elias J, Kelley JJ, Lin RS and Robson JR. 1976. influence of certain dietary fibers in serum and tissue cholesterol levels in rats. P J Nutr 106,118-123.

Velthuis-te Wierik EJ, Vandenberg H, Weststrate JA. Vanhethof KH and de Graaf C. 1996. Consumption of reduced-fat products : Effects in parameters of antioxidative capacity. Eur J Clin Nutr 50, 214-219.

Yagi K. 1987. Lipid peroxides and human diseases. Chemistry and Physics of Lipids 45, 337-342.

Yamamoto L, Nagumo T, Takahashi M, Fujihara M, Suzuki Y and lizima N. 1981. Antitumour effect of seaweeds: III. Antitumour effect of extracts from Sargassum. Jap J Exp Med 51, 187-189.

Yamamoto L, Takahashi M, Tamura E, Maruyama H and Mori H. 1984. Antitumor activity of edible marine algae: Effect of crude fucoidan fraction prepared from edible brown sea weeds L-1210 leukemia. Hydrobiologia 116, 145-150.

Yang JL, Suh MJ and Song YS. 1996. Effects of Dietary Fibers on Cholesterol Metabolism in Cholesterol-Fed Rats. J Korean Soc Food Nutr 25, 392-398.

(Received 11 August 2010; Revised 16 August 2010; Accepted 18 September) 